Journal of Istanbul University Faculty of Dentistry

Volume: 48, Number: 3 Pages: 9-16, 2014

\title{
A RADIOGRAPHIC ASSESSMENT OF THE PREVALENCE OF PULP STONES IN PATIENTS WHO PRESENTED TO ATATURK UNIVERSITY FACULTY OF DENTISTRY DEPARTMENT OF ORAL DIAGNOSIS AND RADIOLOGY
}

\author{
Pulpa Taşı Prevalansının Atatürk Üniversitesi Diş Hekimliği Fakültesi Oral Diagnoz ve Radyoloji \\ Anabilim Dalına Başvuran Hastalarda Radyografik Olarak Değerlendirilmesi \\ Nurcan ÖZAKAR ILDAY ${ }^{1}$, Özkan MILOĞLU², Ömer DEMIRTAŞ², Eren YILDIRIM², \\ Nilgün SEVEN ${ }^{1}$, Ömer SAĞSÖZ ${ }^{1}$
}

\section{ABSTRACT}

Purpose: The aims of this study were to determine the prevalence of pulp stones in a group of Turkish dental patients using panoramic radiographs and dental records, and to report any associations between the presence of pulp stones and age, sex, tooth type, dental status, dental anomalies or systemic diseases.

Materials and Methods: Data were collected through radiographic examination of panoramic radiographs and dental records of 4798 dental patients. The presence of pulp stones was recorded. Chi-square analyses were used to compare the frequency of occurrence $075 \mathrm{f}$ pulp stones between the parameters.

Results: Pulp stones were identified in $168(3.5 \%)$ patients examined. Six hundred twenty $(0.5 \%)$ of 122405 teeth had pulp stones. Gender, tooth type and dental status were correlated with the presence of pulp stones $(\mathrm{p}<0.05)$. No significant association existed between pulp stones and age, dental anomalies or systemic diseases $(\mathrm{p}>0.05)$.

Conclusion: Under the limitations of the present study, pulp stones were detected in 3.5\% of 4798 patients and $0.5 \%$ of 122405 teeth examined using panoramic radiographs. Molars contained significantly more pulp stones than other tooth types. Carious and/or restored first and second molars exhibited a significantly higher prevalence of pulp stones than intact molars. Further studies are needed to clarify the higher pulp stone prevalence in molars and the possible association between the occurrence of pulp stones and pulpal irritations.

Keywords: Dental pulp stone, dental panoramic radiography, oral radiology, prevalence, Turkish population

\section{ÖZ}

Amaç: Bu çalışmanın amaçları; bir grup Türk dental hastada panoramik radyografiler ve dental kayıtlar kullanarak pulpa taşı sıklığının belirlenmesi ve pulpa taşı varlığı ile yaş, cinsiyet, diş tipi, dental durum, dental anomaliler ve sistemik hastalıklar arasında olabilecek ilişkileri bildirmekti.

Gereç ve Yöntem: 4798 hastanın panoramic radyografileri ve dental kayıtları incelenerek veriler toplandı. Pulpa taşı varlığı kaydedildi. Pulpa taşı oluşma sıklığı, ki-kare analizi kullanılarak parametrelerle karşılaştırıldı.

Bulgular: Pulpa taşı, incelenen hastaların 168'inde (\%3.5) tespit edildi. 122405 dişin 620'sinde (\%0.5) pulpa taşı vardı. Cinsiyet, diş tipi ve dental durum pulpa taşı varlığıyla ilişkiliydi $(\mathrm{p}<0.05)$. Pulpa taşları ile yaş, dental anomaliler ve sistemik hastalıklar arasında önemli bir ilişki bulunmuyordu ( $p>0.05)$.

Sonuç: Bu çalışmanın sınırları dahilinde, panoramic radyografiler kullanılarak incelenen 4798 hastanın \%3.5'inde ve 122405 dişin \%0.5'inde pulpa taşı belirlendi. Büyük azılar diğer diş tiplerine göre önemli derecede daha fazla diş taşı içeriyordu. Çürüklü ve/veya restore edilmiş birinci ve ikinci büyük azılar zarar görmemiş büyük azılara göre önemli derece daha yüksek sıklıkta pulpa taşı sergiliyordu. İlerde yapılacak çalışmalarda büyük azılardaki yüksek pulpa taşı sıklığının ve pulpa taşı oluşumu ile pulpal irritasyonlar arasındaki olası ilişkinin açıklanması gerekmektedir.

Anahtar kelimeler: Dental pulpa taşı, dental panoramik radyografi, oral radyoloji, prevalans, Türk popülasyonu

\footnotetext{
*A preliminary report of this study was presented in 1st International Inonu University Faculty of Dentistry Congress, Malatya, 26-28 April 2012.

${ }^{1}$ Department of Restorative Dentistry, Faculty of Dentistry, Ataturk University

${ }^{2}$ Department of Oral Diagnosis and Radiology, Faculty of Dentistry, Ataturk University

${ }^{3}$ Department of Oral Diagnosis and Radiology, Faculty of Dentistry, Kırıkkale University
} 


\section{Introduction}

Calcified structures are fairly common in human dental pulps. Calcification can occur in the dental pulp either as diffuse forms or as discrete calcified stones. Diffuse calcification produces a generalized calcification throughout large areas of pulp chamber and canals. This type of calcification is frequently referred to as "calcific degeneration." The two chief morphological forms of pulpal calcifications are discrete pulp stones (denticles, pulp nodules) and diffuse calcifications. Structurally, pulp stones can be classified as true or false, the former consisting of dentine and being lined by odontoblasts, whereas false pulp stones are formed from degenerating cells of pulp that becomes mineralized. The pattern of calcific degeneration is amorphous and unorganized, appearing as linear strands or columns of calcified material parallel to blood vessels and nerves in the pulp (1-3).

Pulp stones are the foci of calcification in the dental pulp and exist freely in the pulp tissue or become attached to or embedded into the dentine. They are considerably more common in the pulp chamber than in the root canal and may occur in one or several teeth $(3,4)$. They are more commonly located in the coronal than in the radicular parts of the pulp. They range in size from small microscopic particles to large masses that almost obliterate the pulp chamber (1).

Radiographically, pulp stones appear as round or ovoid opacities within the pulp of healthy, diseased or even unerupted teeth in the primary and permanent dentition. They may also occur as a single dense mass or as several small opacities (5).

The formation of pulp stones is still something of an enigma. However, some factors that have been implicated in stone formation include pulp degeneration, inductive interactions between epithelium and pulp tissue (6), circulatory disturbances in pulp (7), orthodontic tooth movement (8), idiopathic factors (9), genetic predisposition (10) and age (6). The formation of pulp stones has also been related to long-standing irritants such as deep dentine fillings, caries and chronic inflammation. Carious lesion stimulates inflammatory changes within the pulp, leading to reparative dentine formation and increased calcification $(3,7)$.

A number of researchers have investigated the association between the presence of pulp stones and dental anomalies (11-13). Pulpal calcifications have also been associated with certain systemic or genetic diseases $(10,14)$. Many prevalence studies have identified various levels of pulp stones (ranging from $3 \%$ to $78 \%$ ) (3).

However, the true prevalence is likely to be higher than the figures from these studies, because pulp stones with a diameter smaller than $200 \mu \mathrm{m}$ cannot be seen on radiographs (15). Females are more frequently affected than males (13). To the best of our knowledge, there have been few reports on the prevalence of pulp stones involving a Turkish population $(5,13,16,17)$.

The aims of this study were to determine the prevalence of pulp stones in a sample of Turkish dental patients using radiographs, and to explore possible associations between pulp stones and age, sex, tooth type, dental status (intact, carious, restored and carious+restored), dental anomalies (including retained teeth, peg lateralis, impacted teeth, transmigrated teeth, dilaceration, supernumerary teeth and taurodontism), and systemic diseases. 


\section{Materials and Methods}

This study was based on the archives of the Department of Oral Diagnosis and Radiology of Ataturk University, in the city of Erzurum, located in the northeast of Turkey. Panoramic radiographs were taken between January 2010 and January 2011 from 4,798 patients (2334 female and 2464 male) referred for routine dental examination and aged 8-72 years (mean age 29.8 years). All panoramic radiographs were obtained using a panoramic radiography device (Planmeca Proline CC 2002, 60-80 kVp, 8-10 mA, 12.8 sec exposure time, Helsinki, Finland) by an $\mathrm{X}$-ray technician with a working experience of 5 years. Radiographs were taken using 6-inch green-sensitive panoramic film (Medical, Konica Co., Japan) and an appropriate cassette-intensifying screen $(15 \times 30 \mathrm{~cm}$, Panoramic X-Ray Film Cassette, Planmeca, Finland-Lanex Screen, Kodak Eastman Co., USA). During filming, exposure adjustments were made based on the characteristics of each individual and the films were developed using an automatic film-processing machine (Velopex, Extra-X, England). The films were scanned and transferred to computer for digital observation. The dental status of each tooth was scored as intact, carious, restored or restored+carious using panoramic radiographs. All other data such as age, gender and systemic diseases were obtained from the patient files. Systemic diseases included in this study were cardiovascular diseases (angina pectoris, myocardial infarction, heart surgery, hypertension, congestive heart failure or arrhythmia), thyroid disturbances, diabetes mellitus, hepatitis, genitourinary disturbances, gastrointestinal disorders and bronchial asthma. Dental anomalies including retained teeth, peg lateralis, impacted teeth, transmigrated teeth, dilacerations, su- pernumerary teeth and taurodontism were detected on radiographs and recorded.

Pulp stones were detected as definite radiopaque bodies inside the pulp cavity and scored as present or absent. An oral radiologist examined the panoramic radiographs using software under appropriate magnification in a dimmed room, focusing attention upon pulp stones, and the examination was repeated by the same oral radiologist after 1 week. Different results were not obtained following the second examination. Data were analyzed with chi-square test using the Statistical Package for Social Sciences (SPSS 16.0; Chicago, IL, USA) Program. A $p$ value of 0.05 was considered statistically significant.

\section{Results}

Pulp stones were identified in 168 (3.5\%) of the 4798 patients examined. Six hundred twenty $(0.5 \%)$ of the 122,405 teeth had pulp stones. Gender, tooth type and dental status were correlated with the presence of pulp stones $(p<0.05)$. No significant association existed between pulp stones and age, dental anomalies or systemic diseases ( $>00.05)$. The prevalence of pulp stones was significantly greater in males compared to females $(\mathrm{p}=0.002)($ Table 1$)$.

Molars contained significantly more pulp stones than those in other tooth types $(p<0.05)($ Table 2). 
Table 1. Distribution of teeth with pulp stones according to gender, age and systemic diseases, and chisquare test results.

\begin{tabular}{|c|c|c|c|c|c|c|}
\hline & & $\mathbf{n}$ & \begin{tabular}{|l|} 
Number of \\
teeth with \\
pulp stones
\end{tabular} & $\begin{array}{l}\text { Percentage } \\
\text { of teeth } \\
\text { with pulp } \\
\text { stones }(\%)\end{array}$ & $\chi^{2}$ & p value \\
\hline \multirow{2}{*}{ Gender } & Female & 2334 & 266 & 11.4 & \multirow{2}{*}{9.397} & \multirow{2}{*}{0.002} \\
\hline & Male & 2464 & 354 & 14.4 & & \\
\hline \multirow{2}{*}{ Age groups } & $8-35$ & 3287 & 425 & 12.9 & \multirow{2}{*}{0.001} & \multirow{2}{*}{0.981} \\
\hline & $36-72$ & 1511 & 195 & 12.9 & & \\
\hline \multirow{2}{*}{$\begin{array}{l}\text { Cardiovascular } \\
\text { diseases }\end{array}$} & Yes & 72 & 10 & 13.9 & \multirow{2}{*}{0.327} & \multirow{2}{*}{0.303} \\
\hline & No & 4726 & 610 & 12.9 & & \\
\hline \multirow{2}{*}{$\begin{array}{l}\text { T h y r o i d } \\
\text { disturbances }\end{array}$} & Yes & 10 & 2 & 20 & \multirow{2}{*}{0.438} & \multirow{2}{*}{0.508} \\
\hline & No & 4788 & 618 & 12.9 & & \\
\hline \multirow[t]{2}{*}{ Diabetes mellitus } & Yes & 43 & 7 & 16.3 & \multirow{2}{*}{0.631} & \multirow{2}{*}{0.48} \\
\hline & No & 4755 & 613 & 12.9 & & \\
\hline \multirow{2}{*}{ Hepatitis } & Yes & 23 & - & 0.0 & \multirow{2}{*}{3.47} & \multirow{2}{*}{0.062} \\
\hline & No & 4775 & 620 & 13.0 & & \\
\hline \multirow{2}{*}{$\begin{array}{l}\text { Genitou rin a ry } \\
\text { disturbances }\end{array}$} & Yes & 25 & 4 & 16.0 & \multirow{2}{*}{0.16} & \multirow{2}{*}{0.545} \\
\hline & No & 4773 & 616 & 12.9 & & \\
\hline \multirow{2}{*}{$\begin{array}{l}\text { Gastrointestinal } \\
\text { disorders }\end{array}$} & Yes & 26 & 3 & 11.5 & \multirow{2}{*}{0.236} & \multirow{2}{*}{0.671} \\
\hline & No & 4772 & 617 & 13.0 & & \\
\hline \multirow{2}{*}{$\begin{array}{l}\text { Bronchial } \\
\text { asthma }\end{array}$} & Yes & 31 & 3 & 9.7 & \multirow{2}{*}{0.287} & \multirow{2}{*}{0.592} \\
\hline & No & 4767 & 617 & 12.9 & & \\
\hline
\end{tabular}

( $p$ values less than 0.05 were considered significant.)

Carious and/or restored first and second molars exhibited a higher prevalence of pulp stones than intact molars $(\mathrm{p}<0.05)$ (Table 3).

\section{Discussion}

Pulp stones are dentine-like calcifications found in pulp tissue. The development process of these calcified bodies is unclear. They are often detected incidentally on ra- diographs (16). It is also reported that pulp stones smaller than $200 \mu \mathrm{m}$ cannot be seen on radiographs (15).

At this point, histological studies are more precise for observing pulp stones, although, using radiographs is the only non-invasive method (18). It should therefore be borne in mind that radiographic prevalence studies cannot prove actually existing conditions. 
N. Özakar İlday, Ö. Miloğlu, Ö. Demirtaş, E. Yıldırım, N. Seven, Ö. Să̆söz

Table 2. Distribution of pulp stones according to tooth types.

\begin{tabular}{|l|l|l|l|}
\hline Tooth type & $\begin{array}{l}\text { Number of ex- } \\
\text { amined teeth }\end{array}$ & $\begin{array}{l}\text { Number of teeth } \\
\text { with pulp stones }\end{array}$ & $\begin{array}{l}\text { Percentage of teeth with } \\
\text { pulp stones (\%) }\end{array}$ \\
\hline Maxillary & 65244 & 336 & $\mathbf{0 . 5 1}$ \\
\hline Central incisors & 9541 & 3 & 0.03 \\
\hline Lateral incisors & 9504 & 1 & 0.01 \\
\hline Canines & 9469 & 1 & 0.01 \\
\hline First premolars & 9469 & 1 & 0.01 \\
\hline Second premolars & 9007 & 9 & 0.10 \\
\hline First molars & 9051 & 194 & 2.14 \\
\hline Second molars & 9203 & 127 & 1.38 \\
\hline Mandibular & 57161 & 284 & $\mathbf{0 . 4 9}$ \\
\hline Central incisors & 9473 & - & 0.0 \\
\hline Lateral incisors & 9560 & - & 0.0 \\
\hline Canines & 9530 & - & 0.0 \\
\hline First premolars & 9475 & 14 & 0.15 \\
\hline Second premolars & 9291 & 23 & 0.25 \\
\hline First molars & 8916 & 142 & 1.59 \\
\hline Second molars & 9116 & 105 & 1.15 \\
\hline Total & 122405 & 620 & $\mathbf{0 . 5 0}$ \\
\hline
\end{tabular}

However, histological examinations may also fail to detect all existing pulp stones (2). This present study was performed with a large group from the Turkish Northeast Anatolian population based on both individuals and teeth numbers. Panoramic radiographs taken for other dental reasons were used. Additional radiographs were not obtained in order to protect patients from hazardous effects of X-rays.

Another advantage of panoramic radiography is that it shows all of the teeth on the same image. It is also possible to magnify the images with minimal resolution reduction when software is used. Setting right exposure adjustments and the working experience of the X-ray technician are important factors in image quality.
The results of the present study revealed a pulp stone prevalence of $0.5 \%$ for the teeth and $3.5 \%$ for the individuals, lower than those reported in the other studies of Turkish dental patients $(5,13$, 16, 17). Pulp stone prevalence findings in the Turkish population reported by other researchers were as follows: Sener et al. (5), $4.8 \%$ of teeth and $38 \%$ of patients; Gulsahi et al. (13), 5\% of teeth and $12 \%$ of patients; Sisman et al. (16), 15\% of teeth and $57.6 \%$ of patients; and Colak et al. (17), $27.8 \%$ of teeth and $63.6 \%$ of patients. There are conflicting results for the prevalence of pulp stones in the literature (17). 
Table 3. Distribution (\%) of teeth with pulp stones according to dental status and dental anomalies.

\begin{tabular}{|l|l|l|l|l|l|}
\hline & & $\begin{array}{l}\text { First } \\
\text { premolars }\end{array}$ & $\begin{array}{l}\text { Second } \\
\text { premolars }\end{array}$ & $\begin{array}{l}\text { First } \\
\text { molars }\end{array}$ & $\begin{array}{l}\text { Second } \\
\text { molars }\end{array}$ \\
\hline \multirow{4}{*}{$\begin{array}{l}\text { Dental } \\
\text { status }\end{array}$} & Intact & $14(2.26)$ & $7(1.13)$ & $12(1.94)$ & $2(0.32)$ \\
\cline { 2 - 6 } & Restored & - & $4(0.65)$ & $51(8.23)$ & $7(1.13)$ \\
\cline { 2 - 6 } & Carious & - & $1(0.16)$ & $16(2.58)$ & $49(7.9)$ \\
\cline { 2 - 6 } & Restored+carious & $1(0.16)$ & $20(3.23)$ & $257(41.45)$ & $174(28.06)$ \\
\hline \multirow{5}{*}{$\begin{array}{l}\text { Dental } \\
\text { anomalies }\end{array}$} & Retained teeth & - & - & - & - \\
\cline { 2 - 7 } & Peg lateralis & - & - & - & - \\
\cline { 2 - 7 } & Impacted teeth & - & - & - & - \\
\cline { 2 - 6 } & $\begin{array}{l}\text { Transmigrated } \\
\text { teeth }\end{array}$ & - & - & - & - \\
\cline { 2 - 7 } & Dilaceration & $1(0.16)$ & - & - & $1(0.16)$ \\
\cline { 2 - 6 } & $\begin{array}{l}\text { Supernumerary } \\
\text { teeth }\end{array}$ & - & - & - & - \\
\cline { 2 - 6 } & Taurodontism & $2(0.32)$ & $1(0.16)$ & $8(1.29)$ & $6(0.97)$ \\
\hline
\end{tabular}

The prevalence of pulp stones may vary due to ethnic variations and geographical differences (17) and also due to study design including type of radiograph and techniques used (19). Another possible explanation is variation in sample size (5).

A decrease in the number of pulp cells and fibrous generation occurs with advancing age. Fat deposition may take place in this tissue and calcification commonly occurs in these deposits (3). In this study, patients were divided into two groups according to age, one group aged between 8 and 35 and the other between 36 and 72 . There was no difference in terms of prevalence between the two groups. Sener et al. (5) reported similar findings, and pulp stone prevalence has been reported to increase with age in other studies $(11,13,17,19)$. In agreement with our findings, some researchers have reported a higher prevalence in females $(5,16,17)$, while others have reported no difference between the genders $(11,13,18)$. Restotions and caries have been considered as irritations possibly associated with pulp stones in the literature (3). In accordance with the literature, carious and/or restored molars had more pulp stones compared with intact molars in this study. Ranjitkar et al. (18) and Sener et al. (5) reported similar results, whereas Gulsahi et al. (13) found no difference in prevalence.

There was no difference in pulp stone occurrence between mandible and maxilla. This result was in agreement with some previous studies $(5,11,13)$. Other studies have reported a higher prevalence of pulp stones in the maxilla (16-18).

In terms of tooth type, molars had statistically more pulp stones than those in other teeth. This finding is also compatible with other studies $(13,17,18)$. In the literature, this is attributed to molars being the largest teeth and providing a better blood supply to the pulp tissue (11), and to their having the greatest chewing force in the arch (16). However, the dental status of molars in this study was different to that of other teeth. The highest ratio of carious and/or restored to intact teeth with pulp stones 
was in the molars (39.6), and in premolars, this ratio was only 1.2 as shown in Table 3 . Therefore, in addition to the explanations suggested by other authors, the higher pulp stone prevalence in molars may also be caused by pulpal response to irritants. Further studies are needed to clarify the higher pulp stone prevalence in molars.

External stimuli, such as caries, may trigger pulp stone formation. Pulp stones are calcified structures, in which the developmental factors involved are largely unknown. Clinical significance may not go beyond difficulties in root canal treatments. However, it has been suggested that some idiopathic pain may be caused by pulp stones. These structures may be idiopathic or induced by local and/or systemic factors (3).

Nayak et al. (20) investigated the correlation between systemic disorders and prevalence of pulp stones. Patients with cardiovascular disorders, diabetes mellitus (Type II), autoimmune disorders, dental wear defects and patients without systemic disorders representing the control group were included. Significant differences were found, the highest number of pulp stones being reported in patients with cardiovascular disorders. Nayak et al. (20) suggested that dental radiography could be used for early identification of potential cardiovascular disease. Our results revealed no correlation between pulp stone prevalence and systemic disorders. Another study also reported no such association (13).

In terms of the relation between pulp stone prevalence and dental anomalies, different results have been reported. Hamasha et al. (11) determined a high incidence of pulp stones with dilacerations, impactions, taurodontism and enamel pearls. In agreement with Gulsahi et al. (13) no significant association was determined as to dental anomalies in our study.

\section{Conclusion}

Under the conditions of the present study, pulp stones were detected in $3.5 \%$ of the patients and $0.5 \%$ of the teeth. The study was performed using panoramic radiographs and revealed a lower pulp stone prevalence than that of other studies in the Turkish population. On the other hand, given the large sample size, this study may provide additional information about the dental features of the Turkish population. To establish the correlation of pulp stones with systemic diseases or dental anomalies, further studies are warranted.

\section{References}

1. Bevelander G, Johnson PL. Histogenesis and histochemistry of pulpal calcification. J Dent Res 1956;35(5):714-22.

2. Moss-Salentijn L, Hendricks-Klyvert M. Calcified structures in human dental pulps. J Endod 1988;14(4):184-9.

3. Goga R, Chandler NP, Oginni AO. Pulp stones: a review. Int Endod J 2008;41(6):457-68.

4. Major IA, Fejerskov O. Histology of the human tooth. 2nd ed., Copenhagen: Munksgaard, 1979.

5. Sener S, Cobankara FK, Akgünlü F. Calcifications of the pulp chamber: prevalence and implicated factors. Clin Oral Investig 2009;13(2):209-15.

6. Hillmann G, Geurtsen W. Light-microscopical investigation of the distribution of extracellular matrix molecules and calcifications in human dental pulps of various ages. Cell Tissue Res 1997;289(1):145-54.

7. Sundell JR, Stanley HR, White CL. The relationship of coronal pulp stone formation to experimental operative procedures. Oral Surg Oral Med Oral Pathol 1968;25(4):579-89. 
8. Stenvik A, Mjor IA. Epithelial remnants and denticle formation in the human dental pulp. Acta Odontol Scand 1970;28(5):72-8.

9. Siskos GJ, Georgopoulou M. Unusual case of general pulp calcification (pulp stones) in a young Greek girl. Endod Dent Traumatol 1990;6(6):282-4.

10. Vandenberghe JM, Panther B, Gound TG. Pulp stones throughout the dentition of monozygotic twins: a case report. Oral Surg Oral Med Oral Pathol Oral Radiol Endod 1999;87(6):749-51.

11. al-Hadi Hamasha A, Darwazeh A. Prevalence of pulp stones in Jordanian adults. Oral Surg Oral Med Oral Pathol Oral Radiol Endod 1998;86(6):730-2.

12. Uslu O, Akcam MO, Evirgen S, Cebeci I. Prevalence of dental anomalies in various malocclusions. Am J Orthod Dentofacial Orthop 2009;135(3):328-35.

13. Gulsahi A, Cebeci AI, Ozden S. A radiographic assessment of the prevalence of pulp stones in a group of Turkish dental patients. Int Endod J 2009;42(8):735-9.

14. Bauss O, Neter D, Rahman A. Prevalence of pulp calcifications in patients with Marfan syndrome. Oral Surg Oral Med Oral Pathol Oral Radiol Endod 2008;106(6):e56-61.

15. Moss-Salentijn L, Klyvert MH. Epithelially induced denticles in the pulps of recently erupted, noncarious human premolars. J Endod 1983;9(12):554-60.

16. Sisman Y, Aktan AM, Tarim-Ertas E, Ciftci ME, Sekerci AE. The prevalence of pulp stones in a Turkish population. A radiographic survey. Med Oral Patol Oral Cir Bucal 2012;17(2):e212-7.

17. Colak H, Celebi AA, Hamidi MM, Bayraktar Y, Colak T, Uzgur R. Assessment of the prevalence of pulp stones in a sample of Turkish Central
Anatolian population. ScientificWorldJournal 2012;2012:804278.

18. Ranjitkar S, Taylor JA, Townsend GC. A radiographic assessment of the prevalence of pulp stones in Australians. Aust Dent J 2002;47(1):36-40.

19. Udoye C, Sede M. Prevalence and analysis of factors related to ooccurrence of pulp stone in adult restorative patients. Ann Med Health Sci Res 2011;1(1):9-14.

20. Nayak M, Kumar J, Prasad LK. A radiographic correlation between systemic disorders and pulp stones. Indian J Dent Res 2010;21(3):369-73.

\section{Corresponding Author: \\ Ömer SAĞSÖZ}

Department of Restorative Dentistry

Faculty of Dentistry Ataturk University

Erzurum / TURKEY

Phone: +905534290938

e-mail: omer.sagsoz@atauni.edu.tr 